\title{
ON THE MULTIPURPOSE USE OF A PORTABLE NEUTRON SOURCE
}

\author{
E.L. Kuplennikov, A.N. Vodin, O.S. Deiev, S.S. Kandybei, S.N. Olejnik, \\ A.F. Stoyanov, I.S. Timchenko, V.S. Trubnikov, V.A. Tsymbal \\ National Science Center "Kharkov Institute of Physics and Technology”, Kharkiv, Ukraine \\ E-mail:kupl@kipt.kharkov.ua
}

The possibility of creating a multipurpose complex for generating a reference field of thermal neutrons based on a portable neutron source (PNS) is considered. It has been shown that our method can be used to detect fissile materials without determining their isotopic composition during an inspection of the hand luggage of passengers, mail, etc. The PNS multipurpose complex will allow to indirectly indicating the possible presence of chemical explosives in the test samples, as well as cadmium and boron, which possibly hide fissile elements from detection. The paper gives recommendations on the use of the most effective instruments and equipment.

PACS: 07.85.Fv, 61.80.Cb

\section{CREATION OF A REFERENCE NEUTRON FIELD}

Laboratory practice shows, that the most accessible and widely used devices for calibrating and studying the parameters of detectors are constructions based on reference neutron fields of radionuclide sources. This is because by placing emitters in different moderating mediums, it is possible to create a reference radiation field with different characteristics. A hydrogen-containing medium, most frequently polyethylene, is used as a moderator. The nomenclature of such sources is extensive. Their properties depend on the radioisotope used, core size, design, materials used, etc. Most often, two types of reference fields based on certified fast neutron emitters, such as ${ }^{252} \mathrm{Cf}$ or ${ }^{239} \mathrm{Pu}-\mathrm{B}$, are preferred.

In [1], the ${ }^{239} \mathrm{Pu}-\mathrm{Be}$ source of fast neutrons was used to determine the dose of thermal neutrons. It was placed in a polyethylene sphere with a diameter of $190 \mathrm{~cm}$ and with a cylindrical cavity in the center with a diameter of $58.5 \mathrm{~mm}$ and a height of $123 \mathrm{~mm} \mathrm{[2].} \mathrm{The} \mathrm{thermal} \mathrm{neu-}$ trons flux density $\Phi$ at a distance $R$ from the center of the sphere was calculated by the formula $\Phi=\Omega \cdot 0.11 /\left(4 \pi R^{2}\right)$. The ratio of the thermal neutrons flux to the total flux of the ${ }^{239} \mathrm{Pu}-\mathrm{Be}$ source $\Omega$ was taken equal to 0.11 with an error of $7 \%$ [2].

Test measurements were carried out in an open $2 \pi$ geometry above a concrete floor level at $150 \mathrm{~cm}$ height. To check the reproducibility of the results in different conditions and to exclude the influence of a geometric factor arising at short distances, the DKS-96 dosimeter sensor, was placed at distance $R=70,150$, and $300 \mathrm{~cm}$. DKS-96 dosimeter calibrated in a way to have an error of $\leq 10 \%$. For a given geometry condition one can treat the radioactive source and the detector as a point like objects and at the same time, the contribution of the dispersed radiation does not exceed $2 \%$.

Note that neutron sources were also created based on linear electron accelerators. For example, a facility for generating thermal $0.5 \cdot 10^{-3} \ldots 0.5 \mathrm{eV}$ and epithermal neutrons $0.4 \mathrm{eV} \ldots 20 \mathrm{keV}$ [3], based on the use of delayed fission neutrons, was proposed at the NSC KIPT [3]. Neutrons were obtained upon activation of a ${ }^{238} U$ target with $2 \%$ enrichment of ${ }^{235} \mathrm{U}$ by an electron beam. After 3 minutes of irradiation, the sample becomes a source of delayed neutrons and is automatically dumped into the receiver of thermal and epithermal neutrons. A preliminary experiment was conducted on an electron beam of $20 \mathrm{MeV}$, with a power of $9 \mathrm{~W}$. The delayed neutron flux density was $6 \cdot 10^{-5} \mathrm{n} \cdot \mathrm{cm}^{-2} \cdot \mathrm{s}^{-1}$. The magnitude $(2 \ldots 3) \cdot 10^{9} \mathrm{n} \cdot \mathrm{cm}^{-2} \cdot \mathrm{s}^{-1}$ required for neutron capture therapy is planned by the authors by increasing the ${ }^{235} \mathrm{U}$ enrichment to $\sim 20 \%$ and the beam power to $1.5 \ldots 3 \mathrm{~kW}$.

In current work, it is proposed to obtain a thermal neutrons reference field based on a polyethylene moderator-sphere and a portable neutron source (PNS) [4, 5] under the condition of a stable neutron flux with accuracy no worse than that of certified radioisotope sources. Note that, as in any other moderator, the thermal spectrum of PNS will be enriched in neutrons of higher energies, including $\sim(10 \mathrm{eV} \ldots 5 \mathrm{keV})$ range.

The principle of operation of PNS is as follows. Accelerated deuterons of the cascade accelerator are directed into a narrow ion guide, passing through which, the particles are focused on a thick ${ }^{9} \mathrm{Be}$ target $10 \cdot 10 \mathrm{~mm}$ in size. Neutrons are generated as a result of the reaction ${ }^{2} \mathrm{H}+{ }^{9} \mathrm{Be} \rightarrow{ }^{10} \mathrm{~B}+\mathrm{n}$. The length of the accelerating tube is $\leq 0.6 \mathrm{~m}$. The distance between the exit point from the accelerator gap and the target is $\leq 0.4 \mathrm{~m}$. The beam diameter on the target is $\leq 6.8 \mathrm{~mm}$. The expected neutron intensity is $\sim 10^{9} \mathrm{n} \cdot \mathrm{s}^{-1}$ at an angle of $4 \pi$, the average energy is $\sim 2.5 \mathrm{MeV}$.

The advantage of this design is the absence of a powerful radiation source since neutrons are created only during the authorized inclusion of a cascade accelerator. Also, the use of isotopes is much more expensive than the work of PNS. The main types of sources that are produced in Russia and their characteristics are given in $[5,6]$.

Since the expected yield flux of fast neutron from ${ }^{9} \mathrm{Be}(\mathrm{d}, \mathrm{n})$ reaction (about $\left.10^{9} \mathrm{n} \cdot \mathrm{s}^{-1}\right)$ is higher than that of ${ }^{239} \mathrm{Pu}$-Be (up to $(5.00 \pm 1.00) \cdot 10^{7} \mathrm{n} \cdot \mathrm{s}^{-1}$ ) and also higher then ${ }^{252} \mathrm{Cf}\left(2.1 \cdot 10^{5} \ldots 2.7 \cdot 10^{7}\right) \mathrm{n} \cdot \mathrm{s}^{-1}$, one can expect that the generation of the thermal neutron with the help of polyethylene sphere will be correspondingly higher. The main components of the PNS are shown in Fig. 1.

The size of the polyethylene sphere can be estimated from an analysis of the energy dependence of the detector sensitivity (EDoS) obtained by irradiating the sphere with an external certified radioisotope source, for example, ${ }^{239} \mathrm{Pu}-\mathrm{Be}$.

Fig. 2 shows EDoS measured by the LiJ(Eu) crystal [7] as a function of the diameter of the polyethylene sphere and the neutron energy $E_{\mathrm{n}}$. 


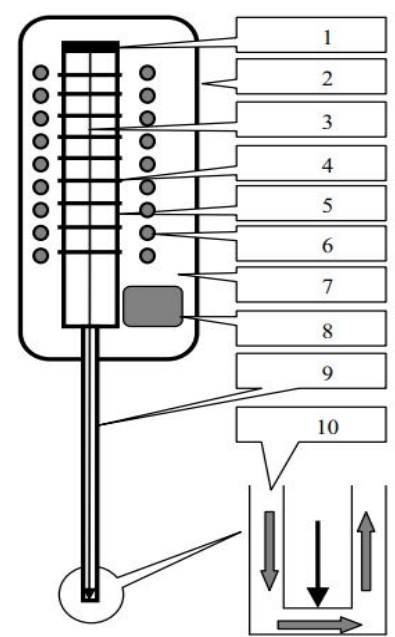

Fig. 1. Schematic view of PNS complex:

1 -deuteron source; 2 -the outer shell; 3 -deuteron beam; 4 -accelerating electrodes; 5 -vacuum tube; 6 -gradient rings; 7 -Elegaz; 8 -vacuum pump; 9 -ion channel; 10 - water

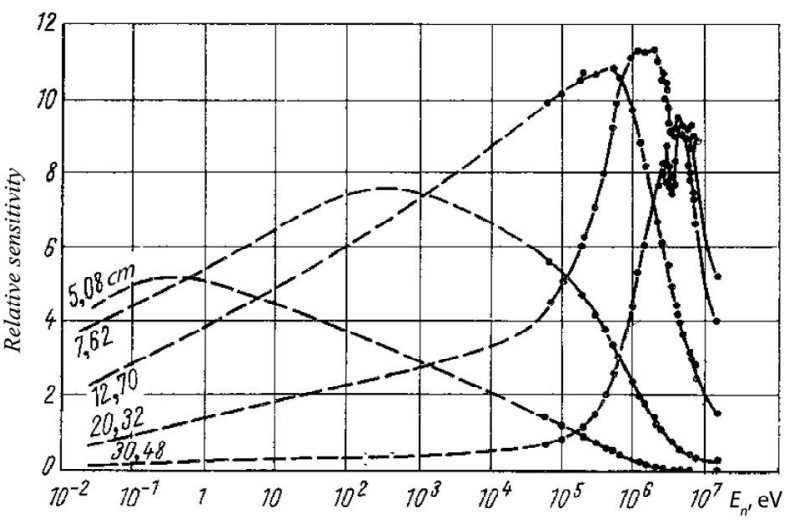

Fig. 2. EDoS for LiJ(Eu) detector as a function of $E_{n}$

As we can see, at sphere diameter of about $\sim 20 \mathrm{~cm}$, external neutrons with an average energy of $\sim(1 \ldots 4.5) \mathrm{MeV}$ generates the maximum number of thermal neutrons in the center of the sphere. Similar dependencies were measured using various neutron counters, and also were calculated based on modern mathematical models. In particular, in [7], EDoS estimates have been done for detectors made from indium foils. The calculations were done also for proportional ${ }^{3} \mathrm{He}(\mathrm{n}, \mathrm{p})^{3} \mathrm{H}$ counter. The sensitivity matrix was calculated using the MCNP and HADRON models. It turned out that in all cases, with a sphere diameter of $\sim 20 \mathrm{~cm}$, the maximum number of thermal neutrons generated by the ${ }^{239} \mathrm{Pu}-\mathrm{Be}$ source is observed in the center of the sphere. When the ${ }^{239} \mathrm{Pu}-\mathrm{Be}$ radioisotope is placed in the center of the sphere, the PE layer for optimal neutron deceleration should be $\sim 20 \mathrm{~cm}$. Since the average neutron energy of the PNS $E_{\mathrm{n}} \sim 2.5 \mathrm{MeV}$ is in the region of the maximum EDoS, the optimal moderator layer necessary to obtain the highest number of thermal neutrons in the center of the sphere should be about $20 \mathrm{~cm}$.

To minimize the leakage of thermal neutrons from the sphere, it should be surrounded by a neutron reflector: $\mathrm{D}_{2} \mathrm{O}$ heavy water, ${ }^{9} \mathrm{Be}$ beryllium, or ${ }^{12} \mathrm{C}$ graphite. The most practical and relatively cheap material is ${ }^{12} \mathrm{C}$. In the process of collisions with nuclei, a thermal neutron has 999 chances out of 1000 to scatter and only 1 chance out of a thousand to be absorbed [8]. The reflectivity of carbon at a thickness of $40 \mathrm{~cm}$ is 0.892 . Therefore, a layer of $\leq 40 \mathrm{~cm}$ is sufficient for most of the thermal neutrons to be reflected.

To create a reference field of thermal neutrons based on a polyethylene moderator-sphere and PNS, it is necessary to take the following steps: a) to develop and create a neutrons moderator, including a ${ }^{12} \mathrm{C}$ reflector; b) estimate the deceleration, absorption, and yield of neutrons from the polyethylene sphere, including the reflector; c) find the analytical dependence of the flux density of the thermal neutrons depending on the distance to the irradiated object. Testing of the prototype should be done at the experimental area of RDC "Accelerator" NSC KIPT after preparation and implementation of all necessary technical and economic requirements.

\section{ESTIMATION OF DECAYING MATERIAL DETECTION PROBABILITY}

A wide network of transport highways, a significant number of boundary checkpoints increases the chance of unauthorized movement of nuclear materials, explosives, drugs. Only the introduction of modern detection systems will allow us to successfully counteract the smuggling of prohibited goods. Special attention at airport custom terminals is paid to detection of fissile materials, explosives, drugs (since approximately half of the total number of incidents of the movement of prohibited substances is their placement in hand luggage [9]). There are many nuclear-physical methods for solving this problem, and one of them is the activation of cargo by thermal neutrons, registration, and analysis of induced reaction products.

Typically, to obtain the thermal neutrons flux necessary to trigger a forced decay of nuclear materials, standard fast neutrons emitters based on the $(\alpha, n)$ reaction of spontaneous ${ }^{252} \mathrm{Cf}$ decay are used. The second option is the pulse generators. The $(\alpha, n)$-emitters have a continuous spectrum and a high level of $\gamma$-background. These sources in various modifications are used in many fields of modern science and technology $[5,10]$.

Existing non-destructive testing methods are aimed, first of all, at determining the mass and composition of decaying materials in confined volumes that cannot be opened. If we consider the installations of the first line of defense used to prevent the circulation of fissile elements (without determining the isotopic content), then their design and operation must satisfy the following basic conditions [11]:

- during the measurement time (about $5 \ldots 7 \mathrm{~s}$ ), it is necessary to obtain the information concerning the presence of decaying materials in the inspected object with a confidence level of $99.9 \%$;

- the output of the source $\left(10^{7} \ldots 10^{8}\right) \mathrm{n} \cdot \mathrm{s}^{-1}$ (determined by the radiation situation of the environment);

- option to turn off the radiation source between working cycles;

- impossibility of radioactive contamination even in the case of the destruction of a neutron source;

- the simplicity of design, the small size of radiation protection and low cost of installation; 
- acceptable operating time without replacing the radiation source;

- absence of special requirements for the storage room of radiation source.

Conclusions from [11]:

a) For the conditions described above, there is no radiation hazard associated with the exposure of baggage materials.

b) Ideally, the probability of detection should not depend on the position of decaying material inside the baggage. But in real conditions, there is some no uniform distribution of the flux density of the $\mathrm{TN}$ due to the position of the source relative to the inspected volume. However, according to estimates, the field gradient of the TN is small.

c) Calculations and experimental studies have confirmed the possibility of the creation of a facility for the detection of decaying nuclei using hydrogen-containing moderators and pulsed neutron generators with an output of $10^{7} \ldots 10^{8} \mathrm{~s}^{-1}$. The content of ${ }^{235} \mathrm{U}$, and ${ }^{239} \mathrm{Pu}$ with a mass of $5 \ldots 10 \mathrm{~g}$ can be detected in $5 \ldots 7 \mathrm{~s}$ of operation with a probability of $99.9 \%$ ".

The requirements described above for the successful operation of the facility for the determination of decaying materials are fully consistent with the operating modes of PNS. Therefore, this article focuses on the possibility of detection of radioactive nuclides ${ }^{233,235} \mathrm{U}$ and ${ }^{239} \mathrm{Pu}$, since these are the main components of nuclear reactors and the main components of weapons of mass destruction. Neutrons of any energy can trigger the decay of nuclei, but the largest cross-section corresponds to TN. At $E_{\mathrm{n}}=0.025 \mathrm{eV}$ : $(526 \pm 4),(581 \pm 6)$, and $(751 \pm 10)$ barn (b), respectively, which is hundreds of times higher than the similar values for fast neutrons. Interacting with a thermal neutron, the nucleus divides, emitting in a time of $\sim 10 \ldots 14 \mathrm{~s}$, instantaneous neutrons with maximum energy in the range of $0.6 \ldots 0.8 \mathrm{MeV}$, the average energy of $\sim 2 \mathrm{MeV}$ and $\gamma$-quanta. The average number of neutrons for one decay event for $E_{\mathrm{n}}=0.025 \mathrm{eV}: 2.50,2.43,2.84$ [12]. The energy spectrum of neutrons from decays of ${ }^{233} \mathrm{U},{ }^{235} \mathrm{U}$, and ${ }^{239} \mathrm{Pu}$ is shown in Fig. 3. These spectra are close to each other $[10,12]$. The experimental points are well described by the distribution

$$
N(T)=\sqrt{E_{n}} \cdot e^{\left(-E_{n} / T\right)},
$$

where $T$ is the temperature of the spectrum. In this case, $T=1.31,1.29$, and 1.33 , respectively.

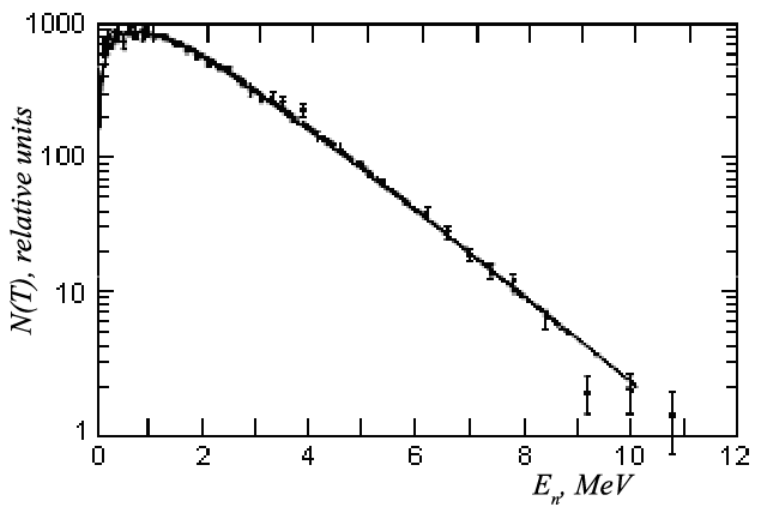

Fig. 3. The energy spectrum of neutrons from decay
The proposed experiment is a sequential series of procedures:

1. A source of FN from PNS with an intensity of $10^{9} \mathrm{n} \cdot \mathrm{s}^{-1}$ is placed in the center of the polyethylene sphere.

2. The neutron flux slowed down to the thermal energies and directed to the object under study.

3. If there are decaying nuclei in the volume, they interact with $\mathrm{TN}$, as a result of this interaction the nuclei fall apart, forming decay fragments, instantaneous and delayed neutrons, $\beta$-particles, antineutrinos, $\gamma$-quanta.

On average, from 7 to $10 \gamma$-quanta are formed per one division, and their average energy is about $1 \mathrm{MeV}$. The number of delayed neutrons, normally, is $\sim 1 \%$ of the number of instant ones. They are emitted by decay products over a period from hundreds of milliseconds up to $54 \ldots 56 \mathrm{~s}$. Their average energy is small. For example, for ${ }^{235} \mathrm{U}$ it is equal to $0.45 \mathrm{MeV}$.

Most nuclear materials emit 10 times more $\gamma$-quanta than neutrons, which sometimes requires the use of a protective shield. When a detector is irradiated with neutrons with energy of $1 \mathrm{MeV}$ in the presence of $\gamma$ radiation with an energy of $1 \mathrm{MeV}$, protection from the lead of $5 \mathrm{~cm}$ thickness absorbs $\sim 0.1 \%$ of neutrons and $90 \%$ of $\gamma$-quanta [13].

As mentioned above, the instantaneous neutron flux should first be slowed down, and only then registered. For slowing down of fast neutrons with energies $1 \ldots 2 \mathrm{MeV}$ to thermal energies, it is recommended to use polyethylene (for gas-filled boron or ${ }^{3} \mathrm{He}$ counters this can be a cylinder with a diameter of $\sim 13 \mathrm{~cm}$ [14]). An important property of PE is that it accumulates most of the thermal neutrons at a certain depth. Particles have already experienced enough collisions and lost almost all of their kinetic energy. If the detector is placed in this region, the probability of detecting particles becomes optimal. The counter is shielded from the background of the thermal neutrons by a thin layer of cadmium. Cadmium strongly absorbs neutrons with energy $\leq 0.4 \mathrm{eV}$ and weakly with $E_{\mathrm{n}}>0.6 \mathrm{eV}$ [15]. Boron can be also used for this purpose, but cadmium is more effective in the case of purely thermal neutrons, while boron shields neutrons were better in the energy range from 0.1 to $10 \mathrm{eV}$ [15].

Widely used counters for detecting TN are devices based on a $\mathrm{LiJ}(\mathrm{Eu})$ crystal or a proportional ${ }^{3} \mathrm{He}$ detector. Detector based on $\mathrm{LiJ}(\mathrm{Eu})$ has the following parameters: an energy resolution of $9 \ldots 10 \%$ for thermal neutrons peak, luminescence time is $\sim 1 \mu$ s, wavelength of the emitted light is $\lambda_{\max }=460 \mathrm{~nm}$, and time resolution is $\sim 0.3 \mu \mathrm{s}$. Scintillators are usually made in the form of washers with a diameter of $10 \ldots 40 \mathrm{~mm}$ and a thickness of $d \sim 2 \ldots 40 \mathrm{~mm}$, which allows them to be placed directly on the photomultiplier tube. Particle detection efficiency $(\varepsilon)$ for natural ${ }^{\text {nat }} \mathrm{Li}$ with a thickness of $d=1 \mathrm{~cm}$ is $\varepsilon \sim 69 \%$ and $\leq 90 \%$ for $d=2 \mathrm{~cm}$. When enriched with ${ }^{6} \mathrm{Li} 94 \ldots 96 \%, \varepsilon \leq 98 \%$ [16]. Due to the high cross-section for the interaction of for thermal neutrons with ${ }^{3} \mathrm{He} 5330 \mathrm{~b}$, proportional ${ }^{3} \mathrm{He}$ counters are very effective for neutron detection. It has a sensitivity to $\gamma$-quanta with an energy of $1 \mathrm{MeV}$ is of the order of $0.0001 .{ }^{3} \mathrm{He}$-detectors are relatively easy to operate and 
highly stable. They withstand irradiation to a fluence of $\sim 10^{13} \mathrm{Bn} \cdot \mathrm{cm}^{-2}$ without serious radiation damage and provide discrimination of $\gamma$-fields with a dose rate up to $\leq 1 \mathrm{R} \cdot \mathrm{h}^{-1}[14]$.

To register neutrons, it is useful to create a set of detectors that form a closed system around the measuring chamber. For example, in [11], 18 helium counters were used. In this case, at the first stage, the simplest set can be composed of three long metal proportional ${ }^{3} \mathrm{He}$-counters SNM-66. Diameter $25.5 \mathrm{~mm}$, length $601.5 \mathrm{~mm}$, operating voltage $1600 \mathrm{~V}$, efficiency to TN $80 \%$ [17]. This sample was selected taking into account the average size of airplane hand luggage allowed $55 \times 40 \times 20 \mathrm{~cm}$ (in length, width, height) or $115 \mathrm{~cm}$ in the sum of three measurements [18].

Among the ${ }^{233,235} \mathrm{U}$ and ${ }^{239} \mathrm{Pu}$ nuclei, the most important in terms of practical use is ${ }^{239} \mathrm{Pu}$. The demand for it is constantly growing - at the beginning of the 21-st century, the annual net increase in plutonium was $\sim 100 \mathrm{t}$. The critical mass of a sphere made of "pure" ${ }^{239} \mathrm{Pu}$ metal with a ${ }^{9} \mathrm{Be}$ reflector $32 \mathrm{~cm}$ thick is $2.47 \mathrm{~kg}$ only [19]. By "pure" is meant the composition: ${ }^{239} \mathrm{Pu}$ $(90 \ldots 95) \%,{ }^{240} \mathrm{Pu}-(1 \ldots 7) \%$, the content of other isotopes does not exceed tenths of a percent.

At the initial stage of the experimental study, ${ }^{239} \mathrm{Pu}$ is more promising than ${ }^{233,235} \mathrm{U}$ due to the maximum crosssection, the largest neutron yield per one decay event, and the presence of resonance in the cross-section at an energy of $\sim 0.3 \mathrm{eV}$ [12] (Fig. 4).

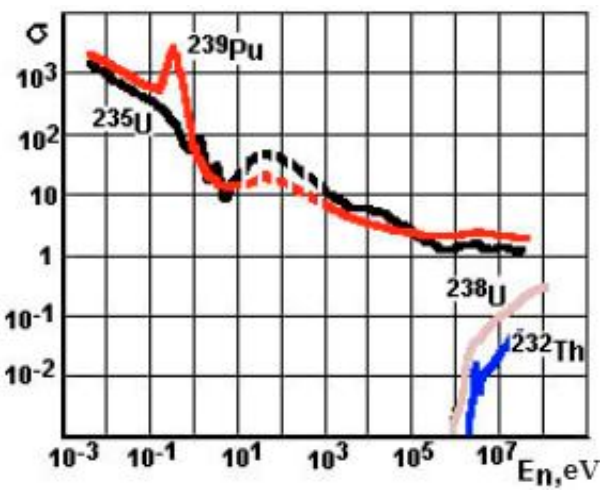

Fig. 4. Decay cross-section of ${ }^{235,238} U,{ }^{239} \mathrm{Pu}$, and ${ }^{232} \mathrm{Th}$ as a function of neutron energy.

Dotted line - resonance region

Creating the complex, the main efforts of the first stage of work will be concentrated at the justification of the use of certain structural elements (with the help of modern software), their sizes and location in space; development and assembly of a thermal neutrons generator based on PNS; estimation of conditions for detecting a minimum number of basic decaying elements; creating reliable radiation protection. It is planned to carry out commissioning, testing and preliminary commissioning of the complex at the test system, the main elements of which are the cascade generator itself, PE moderator, ${ }^{12} \mathrm{C}$ reflector, a set of sensitive detectors and radiation protection. The next stage of work will be experiments to detect the minimum amount of nuclear materials in $5 \ldots 7 \mathrm{~s}$. The work also needs to find out the probability of detecting prohibited materials and false alarm in $\%$.

\section{ADDITIONAL OPTIONS}

Technical advances in the miniaturization of explosive materials (EM) make the task of their detection very important. The main unmasking sign of EM is the certain composition of its components: hydrogen, carbon, nitrogen, and oxygen, which comes in a certain ratio of the concentration of individual nuclei: $\mathrm{O} / \mathrm{N} \mathrm{1-3}$, $\mathrm{C} / \mathrm{N}$ 0.5-2.5, H/ N 1-2. The main component of the structural formula is nitrogen $\left(\sim 10^{21} \mathrm{~cm}^{-3}\right)$. For example, TNT contains $18 \%$ nitrogen, tetryl $24 \%$, hexogen $37 \%$, octogen $39 \%$, nitroglycerin $18 \%$, etc. The nitrogen content in the natural mixture is $99.63 \%$.

One possible option to solve the problem is to use the radiation capture of TN (TNA technology). To determine the concentration of ${ }^{14} \mathrm{~N}$ nuclei, the reaction ${ }^{14} \mathrm{~N}(\mathrm{n}, \gamma){ }^{15} \mathrm{~N}$ is used. The $\gamma$-radiation of a daughter nucleus with the energy of $10.824 \mathrm{MeV}$ has a high intensity of $14 \%$ per neutron captured. The $\gamma$-quanta are fairly reliably recorded at a relatively low neutron flux intensity of $\sim 6 \cdot 10^{7} \mathrm{n} \cdot \mathrm{s}^{-1}$.

To test the technology, two prototypes were created. In one of them, ${ }^{252} \mathrm{Cf}$ was used. The other was a Kaman A-711 type neutron generator (reaction $(\mathrm{d}, \mathrm{d})$ ). TNA tests were successful, which led to many years of successful usage of it at all US airports. In 1996, over $10^{6}$ pieces of luggage were checked. The disadvantage of the method $[9,20]$ is the ability to detect nitrogen only. Also, this method is suffering from the presence of interference from the uncontrolled contribution of $\gamma$ quanta $E_{\gamma}=10038$ and $9298 \mathrm{keV}$ of ${ }^{58,55} \mathrm{Fe}$ isotopes from related objects. More promising future technology is based on fast neutrons and nuclear resonance absorption.

The decaying materials can be smuggled through control points using coatings that absorb $\mathrm{TN}$ (boron, cadmium). An alternative detection system should be used. In the ${ }^{10} \mathrm{~B}(\mathrm{n}, \alpha \gamma)^{7} \mathrm{Li}$ reaction, $\gamma$-quanta are emitted with an energy of $477.6 \mathrm{keV}$ [16] $\left({ }^{10} \mathrm{~B}\right.$ capture crosssection is 4010 b). The thermal neutrons capture crosssection of natural ${ }^{\text {nat }} \mathrm{Cd} \sim 2550 \mathrm{~b}$ is mainly due to the ${ }^{113} \mathrm{Cd}$ isotope $(12.3 \%)$, the cross-section of this isotope is about $20.000 \mathrm{~b}$. In the reaction ${ }^{113} \mathrm{Cd}(\mathrm{n}, \gamma){ }^{114} \mathrm{Cd}$, several gamma-lines are generated. The most intense is $E_{\gamma}=558.6 \mathrm{keV}[21]$.

In this particular case, the most suitable $\gamma$ spectrometer would be a planar detector made of highpurity germanium. It has the best energy resolution and is preferred for detailed spectrometry. Radiation damage manifests itself only starting from an intense neutron flux of $\geq 10^{9} \mathrm{n} \cdot \mathrm{cm}^{-2}$.

\section{CONCLUSIONS}

A multifunctional complex for generating a reference field of thermal neutrons based on a portable neutron source is proposed. The possibility of detection of decaying materials without determining their isotopic composition during the inspection of hand luggage of passengers, mail, etc is discussed. The complex allows to indirectly indicate the possible presence of chemical explosives, also cadmium or boron, in the test volume, which are designed to hide decaying elements from detection. 


\section{REFERENCES}

1. Yu.V. Mokrov, S.V. Morozova. The use of a spherical albedo system for correcting the readings of albedo dosimeters in the neutron fields of the JINR phasotron // Particles and Nuclei, Letters. 2014, v. 11 (2), p. 219-232.

2. GOST 8.355-79. Neutron radiometers. Methods and means of verification. M.: "Publishing House of Standards", 1979.

3. V.I. Kasilov, et al. Generation of thermal and epithermal neutrons on a linear electron accelerator for nuclear medicine // EEJP. 2016, v. 3, p. 64-72.

4. A.F. Stoyanov, A.N. Dovbnya, V.A. Tsymbal. On the possibility of using a portable neutron generator for the treatment of oncological diseases // Problems of Atomic Science and Technology. Series "Nuclear Physics Investigations”. 2017, № 6, p. 172-174.

5. A.N. Dovbnya V.A. Tsymbal, A.F. Stoyanov, et al. Numerical modeling of the effects of neutron flux on organic tissues // Problems of Atomic Science and Technology. Series "Nuclear Physics Investigations”. 2015, № 6, p. 165-168.

6. Guidelines for the customs control of fissile radioactive materials. Appendix 10. https://zakonbase. $\mathrm{ru} /$ con-tent/part/165705? print $=1$.

7. K. Beckurz, C. Wirtz. Neutron physics. M.: “Atomizdat", 1968, $456 \mathrm{p}$.

8. A.V. Sannikov. Development of neutron radiation spectrometry methods at large proton accelerators // SSC RF IHEP. 2006-21, p. 23.
9. G.V. Yakovlev, G.A. Kotelnikov, V.P. Zakharova. Methods for the detection of chemical explosives // Nucl. Tech. Abroad. 1997, v. 3, p. 11-19.

10. S.G. Plachkova. ENERGY. Book 4. 2.1. Physical fundamentals of nuclear reactors. http://energetika. in.ua /ru/books/book-4.

11. V.L. Romodanov et al. Detection of fissile materials in facilities with pulsed neutron sources // Atomic Energy. 2006, v. 101, p. 125-130.

12. I.N. Beckman. Nuclear physics. Lecture 17. Fission of nuclei. p. 24. http://profbeckman.narod.ru/YadFiz.htm

13. T.V. Crane, M.P. Baker. Neutron detectors // Passive non-destructive analysis of nuclear materials. 1991, p. 377-409.

14. J. Sprinkle. Devices for recording the total neutron flux // Passive non-destructive analysis of nuclear materials. 1991, p. 439-461.

15. N.A. Vlasov. Neutrons. M.: "Science", 1971, 462 p.

16. M. Gaisinsky, J. Adly. Radiochemical dictionary of elements. M.: "Atomizdat", 1968, 255 p.

17. M.L. Lamb. Radiation receivers and detectors. M., 2017.

18. https: //www.skyscanner/ru/news/pravila-provozaruchnoi-kladi

19. G.A. Kotelnikov, G.V. Yakovlev. Improving the definition of detection of explosives by characteristic nuclear reactions // PTE. 2002, v. 4, p. 128-129.

20. D.S. McGregor, J.T. Lindsay, R.W. Olsen. Thermal neutron detection using CdZnTe semiconductor detectors // NIM in Phys. Res. A. 1996, v. 381, p. 498501.

Article received 30.03.2020

\section{О МНОГОЦЕЛЕВОМ ИСПОЛЬЗОВАНИИ ПОРТАТИВНОГО ИСТОЧНИКА НЕЙТРОНОВ}

\section{Э.Л. Купленников, А.Н. Водин, А.С. Деев, С.С. Кандыбей, С.Н. Олейник, А.Ф. Стоянов, И.С. Тимченко, В.С. Трубников, В.А. Цымбал}

Рассмотрена возможность создания многофункционального комплекса для генерации опорного поля тепловых нейтронов на основе портативного источника нейтронов (ПИН). Показано, что разработку можно использовать для обнаружения делящихся материалов без определения их изотопного состава при досмотре ручной клади пассажиров, почты и т. д. Кроме того, комплекс ПИН позволит косвенно указывать на возможное присутствие в исследуемом объеме химического взрывчатого вещества, а также кадмия и бора, которые, возможно, скрывают делящиеся элементы от обнаружения. Даны рекомендации по использованию наиболее эффективных инструментов и оборудования.

ПРО БАГАТОЦІЛОВЕ ВИКОРИСТАННЯ ПОРТАТИВНОГО ДЖЕРЕЛА НЕЙТРОНІВ

\section{Е.Л. Купленніков, О.М. Водін, О.С. Дєєв, С.С. Кандибей, С.М. Олійник, О.Ф. Стоянов, І.С. Тімченко, В.С. Трубніков, В.О. Цимбал}

Розглянута можливість створення багатофункціонального комплексу для генерування опорного поля теплових нейтронів на базі портативного джерела нейтронів (ПДН). Показано, що розробка може бути використана для виявлення матеріалів, що діляться, без визначення їх ізотопного складу при огляді ручної поклажі пасажирів, поштових відправлень і т. п. Крім того, комплекс ПДН дозволить побічно вказати на можливу присутність у досліджуваному об'ємі хімічної вибухової речовини, а також кадмію і бору, які можливо приховують елементи, що діляться, від виявлення. Дані рекомендації по застосуванню найбільш ефективних приладів та обладнання. 